\title{
EXPANDING THE POSSIBILITIES OF BUILDING MODERNIZATION: CASE STUDY OF LITHUANIA
}

\author{
Vytautas STANKEVIČIUS ${ }^{a}$, Jūratė KARBAUSKAITÉa, Arūnas BURLINGIS ${ }^{\mathrm{a}}$, \\ Jolanta ŠADAUSKIENÉ ${ }^{a}$, Romaldas MORKVE்NAS ${ }^{\mathrm{b}}$ \\ ${ }^{a}$ Institute of Architecture and Construction of Kaunas University of Technology, \\ Tunelio g. 60, 44405, Kaunas, Lithuania \\ ${ }^{b}$ Faculty of Civil Engineering and Architecture, Kaunas Technology University, \\ Studentu g. 48, 51367, Kaunas, Lithuania
}

Received 27 Feb 2014; accepted 22 May 2014

\begin{abstract}
Energy saving has become one of the foremost priorities in the European Union and a great deal of attention is directed towards the sector of sustainable building. However, the EU members that have an extensive Soviet heritage now face a great difficulty in reducing energy consumption. Since many apartment buildings are in especially poor thermal condition, and the heat supply infrastructure is morally and physically outdated, energy consumption for heating is significant. The modernization (renovation) of such old buildings is impeded not only by legal and technical factors, but also financial and social aspects in regard to the residents. Thus, this paper provides new model of investments and modernization of apartment buildings on the basis of the calculation of energy input per one degree-day of the heated floor area. The presented degree-days calculation method enables the calculation and inter-comparison of data gathered in all European Union member states without taking into account specific climate parameters of each.
\end{abstract}

Keywords: modernization, renovation, energy saving, energy consumption, degree-days, sustainable building.

\section{Introduction}

According to the EU Commission (2000), the dependency on energy supply from countries which are not the members of the European Community and the increase of greenhouse gas emissions stimulate all the EU countries to provide a united energy policy. One of the most important sectors of this policy is the construction and exploitation of buildings as this sector has a high saving potential of primary energy consumption. Following the decisions of the EP and EC (Directive 2010/31/ES 2010), energy consumption in new buildings should be significantly decreased as well as the efforts directed to the implementation of zero-energy buildings in 2020. However, energy consumption is still very high in the existing buildings built before 1995 and its decrease is a great challenge for the residents and governments of the EU member-countries (Risholt et al. 2013; Baek, Park 2012).

Lithuania is one of the EU member-countries which has a lot of Soviet heritage (Fig. 1), particularly in the building sector, which is characterized by low requirements for thermal insulation of building enclosures, as the energy prices were low at the time and large amounts of prefabricated construction volumes were used (Brauers et al. 2012; Juodis et al. 2009). The mean lifetime of such apartment buildings reaches up to one hundred years, so the buildings of the Soviet period still have some lifetime (STR 1.12.06:2002; Malmqvist et al. 2011). Thus, in Lithuania the efficiency of energy supply for residential needs is 1.8 times worse in comparison to other EU countries because of poor thermal insulation of building envelopes and old infrastructure of energy supply (Featuring Country Reports 2011). The modernization of buildings, especially of apartment buildings, is very especially relevant in the discussed circumstances as the living conditions will be improved in parallel to pursuing tasks and requirements established by the EU Directives 2010/31/ES (Andaloro et al. 2010; Morelli et al. 2012; Czakó 2012; Chow et al. 2013).

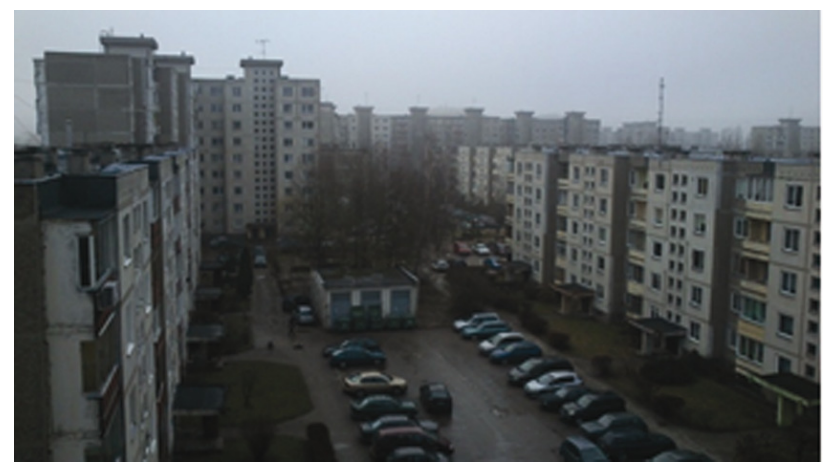

Fig. 1. Square of apartment buildings which was built before 1995 
In regard to set aims, Lithuania involved the modernization of apartment buildings into its strategic plans of sustainable development (Government of Republic of Lithuania 2011). Therefore, the programme of dwelling houses modernization (renovation) was prepared and initiated by the Government of Republic of Lithuania (2004). The general purposes of the program are the following:

$-70 \%$ of apartment buildings (24 000 units) constructed till 1993 will be modernized (renovated) using the assets of households, municipalities, state and EU structural funds;

-Energy consumption for heating of $1 \mathrm{~m}^{2}$ floor area of the modernization (renovated) apartment buildings will be decreased at least by $30 \%$ in comparison to the energy consumption before the modernization (renovated).

In practice only 481 buildings were renovated during the period of 2005-2012 (Statistics Lithuania 2012). At present, the Lithuanian government is improving the legal means of the modernization aiming at the quicker reduction of energy consumption and the growth of renewable energy sources use in the dwelling sector. Nevertheless, the prepared course of projects for the apartment buildings modernization and promotion has significant inaccuracies because of substantial discrepancies between the calculated and real values of energy consumption for heating, reliability in determining the economic efficiency of energy saving measures, risk increase in the activities for end-users (Biekša et al. 2011; Groh 2014).

The development of building modernization in Lithuania is impeded not only by legal and technical aspects of the apartment buildings as the financial possibilities of residents and social aspects of their behaviour also take place (He et al. 2014; Dylewski, Adamczyk 2012; Štreimikienè, Barakauskaitè-Jakubauskienè 2012; Alberini et al. 2013; Anastaselos et al. 2009). Contrary to the common European practice, in Lithuania all the apartments have been privatized and every owner became a co-owner of the whole building. With regard to the number of apartments in a building, there could be a number of co-owners with their own opinion, motivations and financial possibilities for modernization. Then this causes a serious problem when a collective decision on the building modernization is required because the approval of the majority of co-owners is necessary according to Lithuanian law in force (Government of Republic of Lithuania 2004).

As a rule, the income of residents living in old apartment buildings is almost equal to the expenses for heating, and in some cases the amount paid for heating exceeds the rent. Then the state is obliged to cover the heating costs of socially supported residents with low income level. Another big part of residents living in old apartment buildings, i.e. families with medium income level, are not under the state support. Usually the cost of heating requires $30-40 \%$ of family income. Such high heating costs ought to be a strong motive for building modernization, but they are not because residents are deterred by the necessity to urgently acquire a loan, secure it and pay the interest, as well as arrange the modernization project, get it approved, etc. For residents this process seems to be too complicated, untrustworthy and unprofitable in the financial point of view. So the arranged model of modernization promotion was not as successful as planed and went into coordination failure due to the inability of the society to focus on the significant macro-economic projects and financial possibilities without any external support (Dylewski, Adamczyk 2011; Domdayci et al. 2006; Medineckiené, Bjork 2011; Gualberti et al. 2014).

A new more flexible model of modernization for the existing apartment buildings, based on social and economic aspects to promote and stimulate the modernization process, is required in Lithuania. The preparation of a reasonable solution with the involvement of the state, residents and possible investors into the raised issue is the main task of the paper. In parallel, a modified calculation model is prepared for a more reliable determination and comparison of energy consumption values for building heating.

\section{Project description and study data}

\subsection{Methodology}

The modernization process of the apartment buildings in Lithuania is slow because of the lack of investment, as it was indicated in the previous chapter. Residents cannot afford to take loans from the banks and also a big part of them is under social state care. However, the reluctance of residents to have obligations to the banks is the most important reason of the failure in the development of the apartment building modernization. In this case, any advertising and publicity actions have not enough efficien$\mathrm{cy}$, thus, the implementation of another possible model of apartment building modernization is desirable. This model is based on the investments of a special municipal or independent enterprise (for e.g. department of city municipality, agency, construction enterprise, etc.) which invests into the apartment building modernization. Then the three parties participate in the modernization process. The possible obligations and input into the process are presented in Table 1.

The renovation is provided by an investor, while the apartment owners pay for heating to the investor on the former energy consumption level (before renovation) till the investment is fully covered. In order to motivate the residents to approve the modernization, the payment for energy and investment pay-back after the implementation of the modernization project should be lowered by 10 $15 \%$ (assessed as modernization promotion factor in this paper) than it would be paid for heating before the renovation. To make such a payment model effective, the payments for energy by the residents have to be modified in such a way that the financial flows among the residents and the investor are generated in regard to the saved amount of energy. Thus, Figure 2 presents the suggested payment scheme. 
Table 1. Parties of interests and participation in the investment into the apartment building modernization

\begin{tabular}{|c|c|c|c|}
\hline $\begin{array}{c}\text { Parties } \\
\text { of interest }\end{array}$ & $\begin{array}{c}\text { Part of } \\
\text { input, \% }\end{array}$ & Responsibility & Profit \\
\hline $\begin{array}{l}\text { Apartment } \\
\text { owners }\end{array}$ & 0 & - Payment for heating. & $\begin{array}{l}\text { - Less outcome; } \\
\text { - Improvement of indoor climate; } \\
\text { - Longer operation period of the dwelling. }\end{array}$ \\
\hline Investors & 85 & $\begin{array}{l}\text { - Supply of basic investments; } \\
\text { - Warranty on the project implementa- } \\
\text { tion quality; } \\
\text { - Control and safeguard of implemen- } \\
\text { tation terms. }\end{array}$ & $\begin{array}{l}\text { Interest of a municipality: } \\
\text { - Decreased demand for energy resources; } \\
\text { - Decreased input into management of surroundings; } \\
\text { - Social welfare; } \\
\text { - Residual assets applied for other municipal needs. }\end{array}$ \\
\hline State & 15 & $\begin{array}{l}\text { - Selection and appointment of project } \\
\text { coordinator; } \\
\text { - Legal support; } \\
\text { - Control system; } \\
\text { - Arrangement of typical projects for } \\
\text { separate groups of apartment build- } \\
\text { ings with alternatives of solutions } \\
\text { and energy saving measures. }\end{array}$ & $\begin{array}{l}\text { - Creation of workplaces; } \\
\text { - Less unemployment in construction sector; } \\
\text { - Higher activity in economics; } \\
\text { - Decrease of demand in energy resources; } \\
\text { - Expansion of energy independency of the state; } \\
\text { - Improvement of social climate and citizens' } \\
\text { attitude towards the state. }\end{array}$ \\
\hline
\end{tabular}

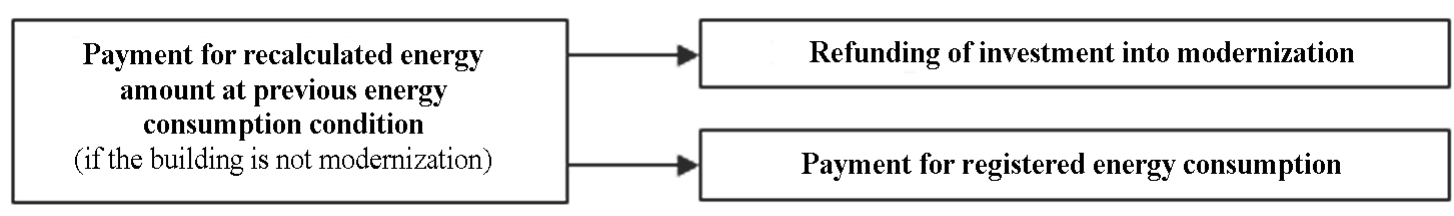

Fig. 2. Principal scheme for refunding of investments after the apartment building modernization

The given payment scheme operates as follows: the investor settles the payment to the energy supplier according to readings of the induction heat meter, whereas the residents pay for heating to the investor according to the calculated heat consumption estimated prior to the modernization. The residents also have another possibility: to pay two bills, one to the energy supplier for the heating supplied after the modernization and the other to the investor for the difference between the heating expenses prior to and after the modernization.

\subsection{Estimation of climate data}

The heating costs directly depend on the energy consumption for building heating, and in turn the energy consumption is related to the indoor and outdoor temperature difference, duration of heating season and thermal characteristics of the building (STR 2.09.04:2008). Therefore, it is necessary to evaluate the trends of outdoor temperature fluctuation as one of significant components in the developed investment model.

The registered day temperatures during the heating seasons of the period 1996-2010 were analysed and their mean values for each heating season were determined. The values of the degree-days for every heating season were obtained as well. Figure 3 presents the distribution of the mean outdoor air temperature and the values of the degree-days during the heating seasons of the considered period with linear trends.

The outdoor air temperature fluctuation of a heating season is evident as it varies from -1.8 to $+2.5{ }^{\circ} \mathrm{C}$ with the mean value of $0.3{ }^{\circ} \mathrm{C}$ according Building Climatology RSN 156-94 of Lithuania (1995). The fluctuation of degree-days value is more modest, and the mean value of standard deviation is about $8 \%$, while the mean value of the degree-days is 3789 (heating season starts at 26.09 and finishes at 03.05; total duration 219 days; indoor air temperature $18^{\circ} \mathrm{C}$ and limit of a heating season is $10^{\circ} \mathrm{C}$ of a mean three days outdoor air temperature) for the city of Kaunas, Lithuania.

The results of outdoor air temperature and degreedays fluctuation analysis will lead to the conclusion to recommend application of the degree-days values for the evaluation of energy consumption in apartment buildings.

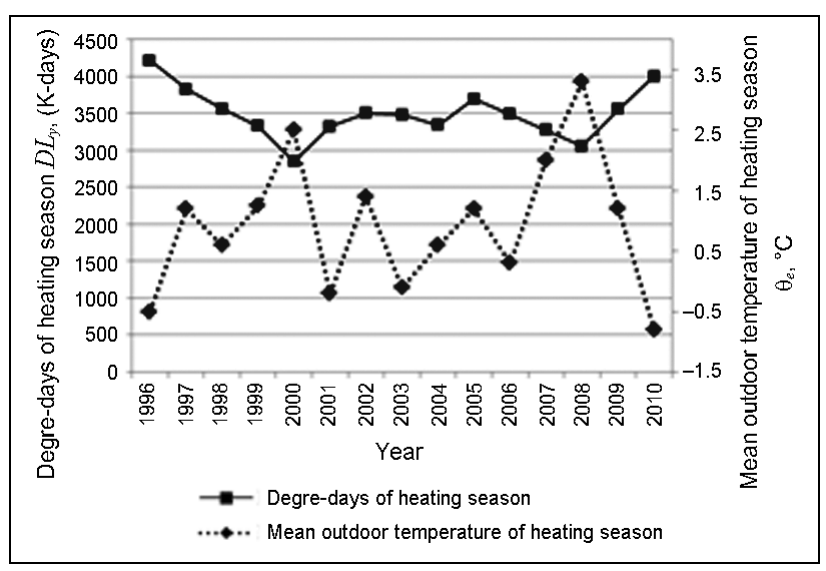

Fig. 3. Distribution of degree-days and mean outdoor temperature of heating seasons of the 1996-2010 period 


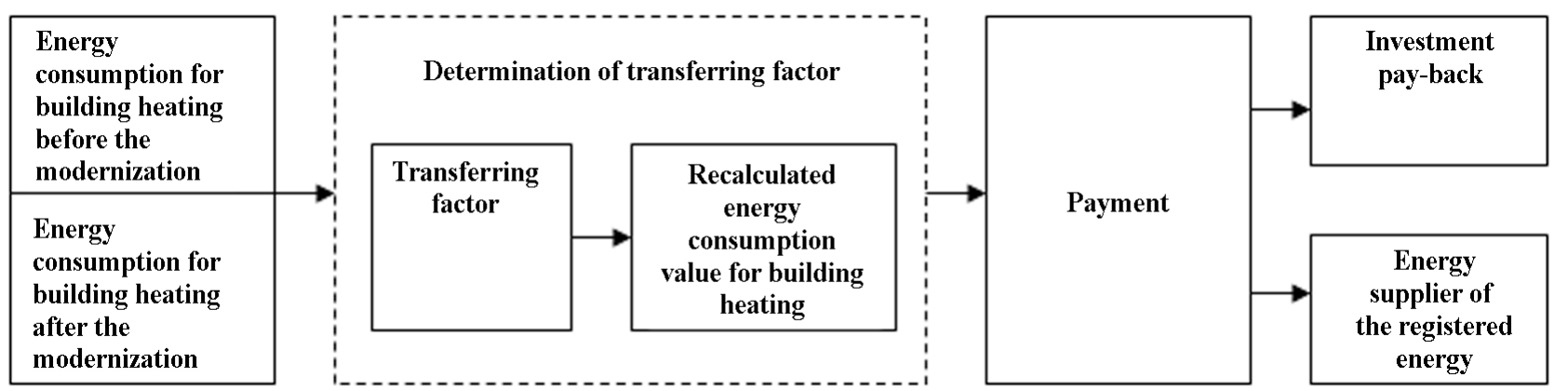

Fig. 4. Implementation scheme for investment model of apartment building modernization

As the reliability of energy consumption evaluation in buildings is very important to the assessment of economic efficiency of modernization (renovation), the use of degree-days as the basement climate data for recalculation of energy consumption is preferable.

\subsection{The investment model of apartment building modernization}

If apartment owners achieved an agreement on the modernization, and negotiation with a possible investor is in progress at the beginning of the modernization process, the reference value of energy consumption for building heating (specific mean energy demand for building heating) should be determined as the mean value of the registered energy consumption of minimum three last heating seasons, $\mathrm{Wh} /(\mathrm{K} \cdot$ days $)$ for $1 \mathrm{~m}^{2}$ of heated floor area.

The energy consumption in the building after modernization is estimated as the registered energy consumption for building heating in regard to the degree-days of the considered period, $\mathrm{Wh} /(\mathrm{K} \cdot$ days $)$ for $1 \mathrm{~m}^{2}$ of heated floor area. The ratio between the determined values will be recognized as a transferring factor at the recalculation of energy consumption value for building heating. An apartment owner should pay for recalculated energy amount according to the conditions before the modernization. This value is determined multiplying the registered energy amount by transferring factor. Such payment order will be kept until the investments will be fully covered. Thus, Figure 4 gives the implementation scheme of the suggested method.

The order of determining the calculated energy consumption values for building heating before and after the modernization is presented below in detail.

\subsubsection{Specific average energy demand for building heating before the modernization}

First, the data on the registered energy consumption for every month heating during the last three heating seasons are collected, including the mean outdoor air temperature $\left(Q_{m o n}, \theta_{e}\right)$. If heating is provided only during a part of the considered month, only this part is estimated. Usually the energy supplier can provide the required data.

Then the value of the degree-days $D L_{y}$ for every heating season is determined according to the mean outdoor air temperature in the considered locality:

$$
D L_{y}=\sum_{i=1}^{n}\left(\theta_{i}-\theta_{e}\right) \cdot t_{m o n}
$$

where: $D L_{y}$ - value of degree-days during the considered heating season, $\mathrm{K} \cdot$ days; $\theta_{e}$ - mean month outdoor air temperature during the considered heating season, ${ }^{\circ} \mathrm{C} ; \theta_{i}-$ mean month indoor air temperature during the considered heating season, ${ }^{\circ} \mathrm{C} ; t_{\text {mon. }}$ - duration of a separate month in the considered heating season, days.

The average value of the degree-days of three heating seasons in the considered apartment building $D L_{a v}$, ( $\mathrm{K} \cdot$ days) is determined as follows:

$$
D L_{a v}=\frac{1}{n} \sum_{i=1}^{n} D L_{y_{i}}
$$

where: $D L_{a v}$ - average three year degree-days value of the considered apartment building, K·days; $D L_{y i}$ - degreedays value during $i$-year's heating season, K.days; $n-$ duration of the considered heating season.

The average energy consumption for heating $Q_{y}$, (MWh per season) is estimated according to Eqns (3) and (4):

$$
Q_{y}=\sum_{i=1}^{n} Q_{\text {mon }_{i}},
$$

where: $Q_{y}$ - energy consumption for heating of building of a separate heating season, MWh per season; $Q_{\text {mon. } i}-$ energy consumption for heating of building during $i$ month, MWh per month; $n$-duration of the considered heating season, months.

$$
Q_{a v}=\frac{1}{n} \sum_{i=1}^{n} Q_{y_{i}}
$$

where: $Q_{y i}$ - energy consumption for heating of building during $i$ heating season, MWh per season; $Q_{a v}$ - average energy demand for heating of building of a separate heating season, MWh per season; $n$ - duration of the considered heating season.

The average specific energy consumption for heating of building for 1 degree-day $q_{a v},\left(\mathrm{kWh} /\left(\mathrm{m}^{2} \cdot \mathrm{K} \cdot\right.\right.$ day $)$ is determined according to Eqn (5): 


$$
q_{a v}=\frac{Q_{a v}}{A \cdot D L_{a v}},
$$

where: $Q_{a v}$ - average energy demand for heating of building of a separate heating season, MWh per season; $q_{a v}-$ average specific energy demand for heating of building related to $1 \mathrm{~m}^{2}$ of heated floor area and 1 degree-day, $\mathrm{kWh} /\left(\mathrm{m}^{2} \cdot \mathrm{K} \cdot\right.$ day $) ; A$ - heated floor area of the considered building, $\mathrm{m}^{2} ; D L_{a v}$ - average three year degree-days value of certain locality, $\mathrm{K} \cdot$ days.

Eqn (5) is applied for the calculation of the specific energy demand of the building prior to the modernization.

\subsubsection{Specific average energy demand for heating of building after the modernization}

To begin, the energy consumption data for heating every month $Q_{\text {mon. }}$ (MWh per month), including the mean outdoor air temperature $\theta_{e}$ and settled mean indoor air temperature $\theta_{\text {in }}$ is registered.

Hence, the value of the degree-days $D L_{f . m o n}$ is determined for a month of a heating season, $(\mathrm{K} \cdot$ day):

$$
D L_{f . \text { mon. }}=\left(\theta_{i}-\theta_{e}\right) \cdot t_{\text {mon. }},
$$

where: $D L_{f . m o n}$ - determined degree-days for a month of a heating season, K·day; $\theta_{e}$ - mean month's outdoor air temperature during the considered heating season, ${ }^{\circ} \mathrm{C} ; \theta_{i}-$ mean month's indoor air temperature during the considered heating season, ${ }^{\circ} \mathrm{C} ; t_{m o n}$ - duration of a separate month in the considered heating season, days.

Monthly energy consumption for heating of building during the heating season is recalculated according to the conditions before the modernization, (MWh per month):

$$
Q_{f . \text { mon. }}=A \cdot q_{a v} \cdot D L_{f . m o n},
$$

where: $Q_{f . m o n}$ - recalculated monthly energy consumption for heating of building during the heating season, $\mathrm{MWh}$ per month; $q_{a v}$ - average specific energy demand for heating of building related to $1 \mathrm{~m}^{2}$ of heated floor area and 1 degree-day $\mathrm{kWh} /\left(\mathrm{m}^{2} \cdot \mathrm{K} \cdot\right.$ day $) ; A$ - heated floor area of the considered apartment building, $\mathrm{m}^{2} ; D L_{a v}$ - average three year value of degree-days of the considered apartment building, K-days; $D L_{f . m o n}$ - determined degree-days for a month of a heating season, $\mathrm{K} \cdot$ day.

Monthly payment for the heating of the entire building (LTL/month) is determined as follows (from 2 February 2002, the Litas (LTL) has been pegged to the euro at a fixed exchange rate of LTL 3.4528 for EUR 1):

$$
S_{\text {mon. }}=k \cdot Q_{f . \text { mon. }} \cdot E,
$$

where: $S_{\text {mon. }}$ - monthly payment for the heating, (LTL/month); $k$ - modernization promotion factor, assessed according to the agreement between the apartment owners and investor (recommended value 0.85-0.9); $Q_{f . m o n}$ - recalculated monthly energy consumption for heating of building during the heating season, MWh per month; $E$ - energy price for heating, LTL $/ \mathrm{kWh}$.
The monthly payment for the supplied energy to the energy supplier by investor is determined according to Eqn (9):

$$
S_{\text {invest.mon. }}=Q_{\text {mon. }} \cdot E \text {, }
$$

where: $S_{\text {invest.mon }}$ - monthly payment for the supplied heating energy to the energy supplier by investor, LTL/month; $Q_{m o n}$ - energy consumption for heating of building of the considered month, MWh per month; $E-$ energy price for heating, $\mathrm{LTL} / \mathrm{kWh}$.

The pay-back of investments of the considered month is the difference between the payments, LTL/month:

$$
\Delta S_{\text {mon. }}=S_{\text {mon. }}-S_{\text {invest.mon. }}
$$

where: $\Delta S_{m o n}$ - pay-back of investments of the considered month is the difference between the payments, LTL/month; $S_{\text {invest.mon. }}$ - monthly payment for the supplied heating energy to the energy supplier by investor, LTL/month; $S_{\text {mon }}$ - monthly payment for the heating, (LTL/month).

Then the expenses of the heating season (distributed as monthly fees) are estimated and paid by the apartment owners, LTL/year:

$$
S_{y}=\sum_{i=1}^{n} S_{\text {mon }_{i}},
$$

where: $S_{\text {mon }_{i}}$. - payment for $i$-month heating, (LTL/month); $S_{y}$ - expenses of the heating season, LTL/year; $n$ - duration of the considered heating season, months.

Then the expenses of the heating season (distributed as monthly fees) are estimated and paid by the investor to the heat supplier, LTL/year:

$$
S_{\text {invest. } y}=\sum_{i=1}^{n} S_{\text {invest.mon }_{i}},
$$

where: $S_{\text {invest.mon }_{i}}$ - investor's payment for the supplied heating energy during $i$-month to the energy supplier, LTL/month; $n$ - duration of the considered heating season, months.

The pay-back of the investments of the heating season, LTL/heating season, is calculated as follows:

$$
\Delta S_{y}=\sum_{i=1}^{n} \Delta S_{\text {mon }_{i}},
$$

where: $\Delta S_{\text {mon }_{i}}-i$-month's pay-back of investments (the difference between the payments for investor and energy supplier), LTL/month; $n$ - duration of the considered heating season, months.

Finally, the reminder of the investments is determined for the whole heating season, LTL:

$$
I=(1+r) \cdot I_{0}-\Delta S_{y},
$$

where: $I$ - reminder of the investments for the whole heating season, LTL; $r$ - interest rate of the investments; 
$I_{o}$ - primary investments, LTL; $\Delta S_{y}$ - investments payback per heating season, LTL/heating season.

All the payments are provided according to this order till all the investments are covered.

\section{Case study}

The analysis of the investments and pay-back flows is provided for the existing modernized building, built in 1974 and containing 100 apartments with the total heated floor area of $4418 \mathrm{~m}^{2}$. Its modernization was finished in 2009 .

The following energy saving measures were implemented to the building:

- additional thermal insulation of external walls and roof;

- replacement of the main domestic hot and cold water supply, sewage and rain drainage pipelines;

-replacement of radiators and heating system pipelines with installation of balancing valves;

-replacement of windows and external doors;

-replacement of heat exchanger in the heat supply sub-station;

- glazing of balconies;

- thermal insulation of basement walls and installation of rain's sloped apron around the basement walls.

The ventilation system is left as it is, i.e. natural exhausting from kitchens, toilets and bathrooms and natural air supply - through window micro-ventilation systems.

The thermal parameters of building envelope before and after the modernization are compared in Table 2.
Table 2. Thermal parameters of building envelope before and after the renovation

\begin{tabular}{l|c|c}
\hline \multirow{2}{*}{$\begin{array}{c}\text { Element of } \\
\text { building envelope }\end{array}$} & \multicolumn{2}{|c}{$\begin{array}{c}\text { Heat transmission coefficient } U, \\
\mathrm{~W} /\left(\mathrm{m}^{2} \cdot \mathrm{K}\right)\end{array}$} \\
\cline { 2 - 3 } & $\begin{array}{c}\text { Before } \\
\text { modernization }\end{array}$ & $\begin{array}{c}\text { After } \\
\text { modernization }\end{array}$ \\
\hline External walls & 1.0 & $\leq 0.2$ \\
\hline Roof & 1.25 & $\leq 0.16$ \\
\hline Basement ceiling & 0.75 & 0.75 \\
\hline Windows & 2.6 & $\leq 1.6$ \\
\hline External doors & 2.5 & $\leq 1.6$ \\
\hline
\end{tabular}

The primary total sum of the investments was estimated to reach $1.75 \mathrm{mln}$. LTL (506 835 EUR) and the planned energy savings amounted to approximately $40 \%$. The actual total sum of the investments was equal to 1.701350 LTL (492 745 EUR), according to the data of Housing Energy Saving Agency under the Lithuanian Ministry of Environment. The share of state support was estimated as 788877 LTL (228 474 EUR), it is $46 \%$, and the investments to be returned were $912474 \mathrm{LTL}$ (264 271 EUR) for this 5-storey apartment building.

The initial data of 2005-2008, necessary to apply to the suggested investment model, were obtained from the heat energy supplier (Table 3 ). The standard mean value of 3789 degree days for the heating season is indicated in the Building Climatology of Lithuania (RSN 156-94 1995). The future rise of heat energy price is assumed to reach 3\% in regard to the recommendations of the European Community.

Table 3. Energy consumption for heating before modernization of the apartment building

\begin{tabular}{l|c|c|c|c|c}
\hline $\begin{array}{c}\text { Heating } \\
\text { season }\end{array}$ & $\begin{array}{c}\text { Energy consump- } \\
\text { tion for heating, } \\
\mathrm{MWh}\end{array}$ & $\begin{array}{c}\text { Mean outdoor tempera- } \\
\text { ture of heating season, } \\
\theta_{e},{ }^{\circ} \mathrm{C}\end{array}$ & $\begin{array}{c}\text { Duration } \\
\text { of heating } \\
\text { season, days }\end{array}$ & $\begin{array}{c}\text { Degree-days of } \\
\text { heating season, } D L_{y}, \\
(\mathrm{~K} \cdot \text { days })\end{array}$ & $\begin{array}{c}\text { Energy consumption } \\
\text { for heating } 1 D L, \\
\mathrm{kWh} /(\mathrm{K} \cdot \mathrm{days})\end{array}$ \\
\hline $2005-2006$ & 435.6439 & -0.52 & 163 & 3698.6 & 117.8 \\
\hline $2006-2007$ & 308.2422 & 3.21 & 184 & 2799.4 & 110.1 \\
\hline $2007-2008$ & 358.1282 & 2.89 & 193 & 2998.4 & 119.4 \\
\hline $\begin{array}{l}\text { Reference energy consumption for heating, } \mathrm{kWh} /(\mathrm{K} \cdot \text { days }), \text { as mean value of } \\
3 \text { heating seasons: }\end{array}$
\end{tabular}

Table 4. Calculation results of pay-back of modernization investments for apartment building

\begin{tabular}{c|c|c|c|c|c|c}
\hline $\begin{array}{c}\text { Heating } \\
\text { season, } \\
\text { year }\end{array}$ & $\begin{array}{c}\text { Degree-days of } \\
\text { heating season } \\
\text { DLy, (K·days) }\end{array}$ & $\begin{array}{c}\text { Payment for heating } \\
\text { before modernization } \\
S_{y}, \mathrm{Lt} / \text { year }\end{array}$ & $\begin{array}{c}\text { Energy } \\
\text { price } \\
E, \mathrm{Lt} / \mathrm{kWh}\end{array}$ & $\begin{array}{c}\text { Actual payment to } \\
\text { the energy supplier } \\
S_{\text {invest.y, Lt/year }}\end{array}$ & $\begin{array}{c}\text { Payment to } \\
\text { investor, } \\
\Delta S_{y}, \mathrm{Lt} / \mathrm{year}\end{array}$ & $\begin{array}{c}\text { Reminder of } \\
\text { investments } \\
I, \mathrm{Lt}\end{array}$ \\
\hline 1 & 3618 & 1535.98 & 0.3 & 614.39 & 921.59 & 11814.7 \\
\hline 2 & 3829 & 1679.75 & 0.31 & 671.90 & 1007.85 & 11131.0 \\
\hline 3 & 3462 & 1567.74 & 0.32 & 627.10 & 940.64 & 10496.1 \\
\hline 4 & 3430 & 1601.79 & 0.33 & 640.71 & 961.07 & 9821.1 \\
\hline 5 & 3401 & 1636.37 & 0.34 & 654.55 & 981.82 & 9104.4 \\
\hline 6 & 4212 & 2086.19 & 0.35 & 834.47 & 1251.71 & 8088.3 \\
\hline 7 & 3733 & 1901.77 & 0.36 & 760.71 & 1141.06 & 7155.6 \\
\hline 8 & 3605 & 1887.57 & 0.37 & 755.03 & 1132.54 & 6203.8 \\
\hline 9 & 4078 & 2192.94 & 0.38 & 877.18 & 1315.77 & 5034.7 \\
\hline 10 & 3298 & 1820.17 & 0.39 & 728.07 & 1092.10 & 4060.8 \\
\hline 11 & 3407 & 1928.54 & 0.4 & 771.42 & 1157.12 & 2990.8 \\
\hline 12 & 3475 & 2016.21 & 0.41 & 806.48 & 1209.72 & 1834.5 \\
\hline 13 & 3858 & 2293.02 & 0.42 & 917.21 & 1375.81 & 472.5 \\
\hline 14 & 3956 & 2407.25 & 0.43 & 962.90 & 1444.35 & -1001.0 \\
\hline
\end{tabular}


Further, Table 4 shows a possible layout of payments due to the building modernization according to the suggested method for an apartment of average floor area of $60 \mathrm{~m}^{2}$. The investments return should amount to 12390 LTL (3 588 EUR) with 3\% of reduced interest rate. This payment seems to be a heavy burden to the most of residents who receive only small and medium income. The research is analysing the Lithuanian building sector and those of other post-Soviet countries points out the interest of residents in little investments with a short pay-back period (Medineckiené, Bjork 2011; Dylewski, Adamczyk 2011; Domdayci et al. 2006). Therefore, the suggested support programme for building modernization is not tempting for apartment owners.

The payment would be fully paid back in $14^{\text {th }}$ year at the assumed energy saving rate of $40 \%$. In this calculation the degree-days of real heating seasons are used as an example. The modernization promotion factor's value 0.9 is applied for the determination of the payment for energy consumption.

\section{Results and discussion}

The estimation of energy consumption efficiency with the application of degree-days is meaningful in all Europe. In different countries, the energy consumption is unequal as it depends on the outdoor climate characteristics and thermal insulation of buildings. During the cold period, energy demand for heating makes up the greater part of the whole energy consumption in the Nordic countries, whereas in the Southern countries the energy is consumed mostly for air cooling and air conditioning (Korolija et al. 2013; Wang et al. 2013; Chua et al. 2013; Budaiwi et al. 2013; Synnefa, Santamouris 2012; Cho et al. 2012; Uihlein, Eder 2010). While planning building renovation, ventilation and air cooling should also be included into the evaluation of results.

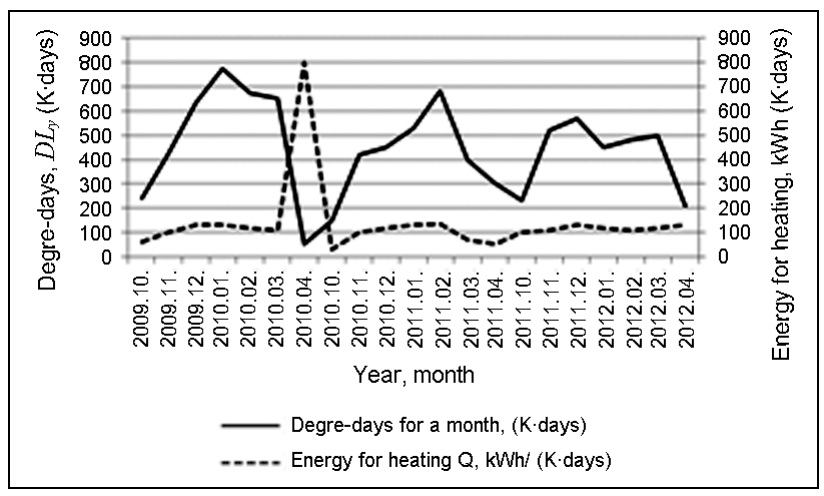

Fig. 5. Energy consumption in apartment building before modernization and outdoor climate data

The results of the analysis of energy consumption for heating of the considered apartment building before and after building modernization are presented in Figures 5 and 6 . Before the modernization, significantly oversized energy consumption is observed during spring time. Thus, the efficiency of heating system regulation is not sufficient. In contract, after the modernization in 2009, the energy consumption for heating decreased and the alteration of it is similar to the changes of outdoor air according given in Figure 6.

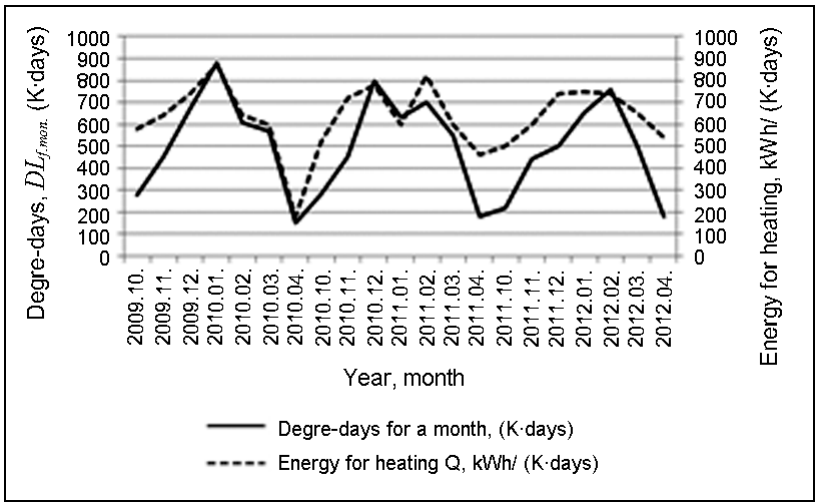

Fig. 6. Energy consumption in apartment building after modernization and outdoor climate data

Furthermore, Table 5 demonstrates actual energy consumption for heating the apartment building after the modernization and the return of investments according to the suggested method. Energy savings reach nearly $50 \%$, at standard deviation of $28 \%$. The results show some lack in the regulation of the heating system, so the energy savings could be increased a little. In comparison to the numeral values in Table 4, the real pay-back period of the investments should be shorter, if energy prices stayed at the present level, or rose.

The order of recalculating energy consumption should include the evaluation of internal heat gains. They usually take up to $10 \%$ in the energy balance of the apartment building of old condition. If the building envelope conforms to the present requirements of Thermal Techniques of Building Enclosures (STR 2.05.01:2005) after the modernization, the internal heat gains will have a more significant impact on the estimation of the degreedays and energy consumption efficiency (Juodis 2013).

After the return of the investments, residents will pay only for the consumed energy to the supplier. It is important that the payments to the investor are provided with respect to the change of energy prices and variation of climate conditions.

The implementation of the suggested investment model would enlarge the modernization possibilities of apartment buildings since the process is rather slow at present. This would result in the reduction of heating input of apartment buildings up to $40-50 \%$. Apart from the reduced bills for heating, apartment owners would obtain a shorter heating season, i.e. approximately 5 months instead of 6 .

In such a case, the state should coordinate the activity on the residents' behalf by solving the financial issues related to the implementation of the modernization programme so that the process of reducing energy input in old apartment buildings does not slow down. If energy prices start rising and its consumption does not decrease, the residents with low income will face serious difficulties in paying the bills, which will lead to the increasing debt to the energy suppliers and thus, negative social consequences (Government of Republic of Lithuania 2011; Streimikienè, Barakauskaitė-Jakubauskienè 2012). 
Table 5. Results of modernization and progress of investment pay-back for apartment building

\begin{tabular}{|c|c|c|c|c|c|c|c|c|c|c|c|c|c|}
\hline \multirow{2}{*}{$\stackrel{\vec{\nabla}}{\vec{\nu}}$} & \multirow{2}{*}{ 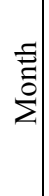 } & \multirow{2}{*}{$\begin{array}{l}0 \\
0\end{array}$} & \multirow{2}{*}{ 咅离 } & \multirow{2}{*}{ 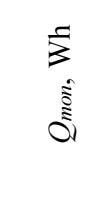 } & \multirow{2}{*}{ 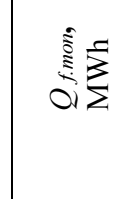 } & \multirow{2}{*}{ 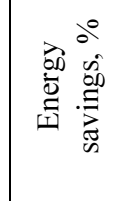 } & \multirow{2}{*}{ xi $\sum_{=}^{E}$} & \multirow{2}{*}{ 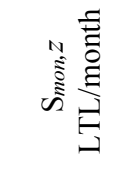 } & \multirow{2}{*}{ 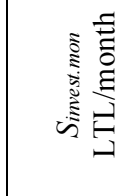 } & \multirow{2}{*}{ 站䓌 } & \multirow{2}{*}{$\stackrel{\vec{\vartheta}}{\vec{\xi}}$} & \multicolumn{2}{|c|}{$\begin{array}{l}\text { Reminder of } \\
\text { investments }\end{array}$} \\
\hline & & & & & & & & & & & & LTL & $\%$ \\
\hline \multirow{3}{*}{ ஓे } & 10 & 4.2 & 262 & 14.894 & 31.317 & 52.44 & 220.00 & 6889.83 & 3276.62 & 3613.21 & \multirow{2}{*}{\multicolumn{3}{|c|}{$(912474-15245.80) * 1.03=$}} \\
\hline & 11 & 3.9 & 423 & 26.941 & 50.524 & 46.68 & 220.00 & 11115.18 & 5926.95 & 5188.22 & & & \\
\hline & 12 & -2.5 & 636 & 46.612 & 75.905 & 38.59 & 220.00 & 16699.04 & 10254.67 & 6444.37 & 15245.80 & 897228.20 & 98.33 \\
\hline \multirow{7}{*}{$\stackrel{\circ}{\circ}$} & 01 & -10.2 & 874 & 77.599 & 104.415 & 25.68 & 251.32 & 26241.34 & 19501.86 & 6739.48 & & & \\
\hline & 02 & -3.9 & 613 & 39.709 & 73.241 & 45.78 & 251.32 & 18406.76 & 9979.54 & 8427.21 & & & \\
\hline & 03 & 0.1 & 555 & 33.165 & 66.278 & 49.96 & 251.32 & 16656.74 & 8334.86 & 8321.87 & & & \\
\hline & 04 & 6.0 & 84 & 1.053 & 10.033 & 89.51 & 251.32 & 2521.47 & 264.62 & 2256.86 & & & \\
\hline & 10 & 4.3 & 274 & 13.289 & 32.727 & 59.39 & 240.00 & 7854.44 & 3189.39 & 4665.04 & & & \\
\hline & 11 & 4.0 & 420 & 29.677 & 501165 & 40.84 & 240.00 & 12039.65 & 7122.41 & 4917.24 & & & \\
\hline & 12 & -7.8 & 800 & 62.630 & 951529 & 34.44 & 240.00 & 22926.93 & 15031.14 & 7895.79 & 49667.86 & 872987.15 & 95.67 \\
\hline \multirow{7}{*}{$\overline{\vec{c}}$} & 01 & -2.9 & 648 & 39.454 & 77.386 & 49.02 & 240.00 & 18572.59 & 9468.87 & 9103.72 & & & \\
\hline & 02 & -7.4 & 711 & 58.028 & 84.946 & 31.69 & 240.00 & 20387.14 & 13926.69 & 6460.45 & & & \\
\hline & 03 & 0.1 & 555 & 33.269 & 66.278 & 49.80 & 240.00 & 15906.67 & 7984.63 & 7922.04 & & & \\
\hline & 04 & 5.9 & 157 & 7.013 & 18.788 & 62.67 & 240.00 & 4509.14 & 1683.20 & 2825.94 & & & \\
\hline & 10 & 5,2 & 230 & 11.384 & 27.519 & 58.63 & 300.00 & 8255.76 & 3415.34 & 4840.41 & & & \\
\hline & 11 & 3.5 & 435 & 25.798 & 51.957 & 50.35 & 300.00 & 15587.05 & 7739.46 & 7847.58 & & & \\
\hline & 12 & 1.9 & 499 & 37.003 & 59.613 & 37.93 & 300.00 & 17883.90 & 11100.81 & 6783.08 & 45783.23 & 852020.04 & 93.37 \\
\hline \multirow{4}{*}{ 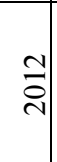 } & 01 & -2.9 & 648 & 49.029 & 77.386 & 36.64 & 300.00 & 23215.74 & 14708.63 & 8507.11 & & & \\
\hline & 02 & -9.1 & 759 & 55.906 & 90.632 & 38.32 & 300.00 & 27189.54 & 16771.83 & 10417.71 & & & \\
\hline & 03 & 1.9 & 499 & 31.890 & 59.613 & 46.50 & 300.00 & 17883.90 & 9567.00 & 8316.90 & & & \\
\hline & 04 & 2.6 & 169 & 9.160 & 20.233 & 54.73 & 300.00 & 6069.99 & 2748.00 & 3321.99 & & & \\
\hline
\end{tabular}

Note: From 2 February 2002, the litas (LTL) has been pegged to the euro at a fixed exchange rate of LTL 3.4528 for EUR 1.

\section{Conclusions}

The new model of investments and modernization of apartment buildings would provide the payments for apartment owners for heating and pay-back of investments according to the $10-15 \%$ less of recent energy consumption level till the end of the pay-back period (1215 years), and in turn, the payment would be divided into a real payment to the heating energy supplier and return of investments. The state would partly refund a successful implementation of the modernization projects.

The implementation of the new investment and modernization model would improve the modernization possibilities of apartment buildings since the process is rather slow at present. This would result in the reduction of heating energy consumption of apartment buildings up to $40-50 \%$. Apart from the reduced bills for heating, apartment owners would obtain a shorter heating season, i.e. approximately 5 months instead of 6 .

Moreover, the modernization of heating systems and their regulation ought to be immediately included into the modernization projects.

Special institutions at municipalities should be established with the purpose to be involved into the implementation of the modernization projects, as local authorities would gain the greatest part of the modernization benefits.

As the reliability of energy consumption evaluation in buildings is very important to the assessment of eco- nomic efficiency of modernization (renovation), the use of degree-days as the basement climate data for recalculation of energy consumption is preferable. The presented degree-days calculation method enables the calculation and inter-comparison of data gathered in all European Union member states without taking into account specific climate parameters of each.

\section{Acknowledgements}

Authors want to thank to Lithuanian District Heating Association for the provided data of heat consumption.

\section{References}

Alberini, A.; Banifi, S.; Kapoor, S.; Ramseier, C. 2013. Energy efficiency investments in the home: Swiss homeowners and expectations about future energy prices, Energy Journal 34(1): 49-86.

http://dx.doi.org/10.5547/01956574.34.1.3

Anastaselos, D.; Giama, E.; Papadopoulos, A. M. 2009. An assessment tool for the energy, economic and environmental evaluation of thermal insulation solutions, Energy and Buildings 41(11): 1165-1171.

http://dx.doi.org/10.1016/j.enbuild.2009.06.003 
Andaloro, A. P. F.; Salomone, R.; Ioppolo, G.; Andaloro, L. 2010. Energy certification of buildings: a comparative analysis of progress towards implementation in European countries, Energy Policy 38(10): 5840-5866. http://dx.doi.org/10.1016/j.enpol.2010.05.039

Baek, C. H.; Park, S. H. 2012. Changes in renovation policies in the era of sustainability, Energy and Buildings 47: 485496. http://dx.doi.org/10.1016/j.enbuild.2011.12.028

Biekša, D.; Šiupšinskas, G.; Martinaitis, V.; Jaraminienè, E. 2011. Energy efficiency challenges in multi-apartment building renovation in Lithuania, Journal of Civil Engineering and Management 17(4): 467-475. http://dx.doi.org/10.3846/13923730.2011.622408

Brauers, W. K. M.; Kracka, M.; Zavadskas, E. K. 2012. Lithuanian case study of masonry buildings from the Soviet period, Journal of Civil Engineering and Management 18(3): 444-456. http://dx.doi.org/10.3846/13923730.2012.700944

Budaiwi, I. M.; Abdou, A. A. A.; Homoud, M. S. 2013. Envelope retrofit and air-conditioning operational strategies for reduced energy consumption in mosques in hot climates, Building Simulation 6: 33-50. http://dx.doi.org/10.1007/s12273-012-0092-5

Cho, J.; Limb, T.; Kim, B. S.; 2012. Viability of datacenter cooling systems for energy efficiency in temperate or subtropical regions: case study, Energy and Buildings 55: 189-197. http://dx.doi.org/10.1016/j.enbuild.2012.08.012

Chow, D. H. C.; Li, Z.; Darkwa, J. 2013. The effectiveness of retrofitting existing public buildings in face of future climate change in the hot summer cold winter region of China, Energy and Buildings 57: 176-186. http://dx.doi.org/10.1016/j.enbuild.2012.11.012

Chua, K. J.; Chou, S. K.; Yang, W. M.; Yan, J. 2013. Achieving better energy-efficient air conditioning - a review of technologies and strategies, Applied Energy 104: 87-104. http://dx.doi.org/10.1016/j.apenergy.2012.10.037

Czakó, V. 2012. Evolution of Hungarian residential energy efficiency support programmes: road to and operation under the Green Investment Scheme, Energy Efficiency 5(2): 163-178. http://dx.doi.org/10.1007/s12053-011-9135-5

Directive 2010/31/EC of the European Parliament and of the Council of 19 May 2010 on the energy performance of buildings (recast), Brussels [online], [cited 26 June 2013]. Available from Internet:

http://eur-lex.europa.eu/LexUriServ/LexUriServ.do?uri $=$ OJ:L:2010:153:0013:0035:EN:PDF

Dylewski, R.; Adamczyk, J. 2011. Economic and environmental benefits of thermal insulation of building external walls, Building and Environment 46(12): 2615-2623. http://dx.doi.org/10.1016/j.buildenv.2011.06.023

Dylewski, R.; Adamczyk, J. 2012. Economic and ecological indicators for thermal insulating building investments, Energy and Buildings 54: 88-95. http://dx.doi.org/10.1016/j.enbuild.2012.07.021

Domdayci, A. O.; Golcu, M.; Pancar, Y. 2006. Optimization of insulation thickness for external walls using different energy-sources, Applied Energy 83(9): 921-928. http://dx.doi.org/10.1016/j.apenergy.2005.10.006

European Commission. 2000. Towards a European strategy for the security of energy supply. Green Paper. Brussels: European Commission. $111 \mathrm{p}$.

Implementing the Energy Performance of Buildings Directive (EPBD). Featuring Country Reports 2010. Brussels: European Commission, 2011.
Government of Republic of Lithuania. 2011. National sustainable development strategy [online], [cited 26 June 2013]. Available from Internet: http://www.am.lt/files/Strategija.pdf

Government of Republic of Lithuania. 2004. Programme of apartment building modernization, 2004. [online], [cited 26 June 2013]. Available from Internet:

www.lrv.lt/bylos/Teises_aktai/2009/08/13575.doc

Groh, S. 2014. The role of energy in development processes The energy penalty: case study of Arequipa (Peru), Energy for Sustainable Development 18: 83-99. http://dx.doi.org/10.1016/j.esd.2013.12.002

Gualberti, G.; Martins, L. F.; Bazilian, M. 2014. An econometric analysis of the effectiveness of development finance for the energy sector, Energy for Sustainable Development 18: 16-27. http://dx.doi.org/10.1016/j.esd.2013.11.009

He, Y. X.; Liu, Y. Y.; Xia, T; Zhou, B. 2014. Estimation of demand response to energy price signals in energy consumption behaviour in Beijing, China, Energy Conversion and Management 80: 429-435.

http://dx.doi.org/10.1016/j.enconman.2014.01.052

Juodis, E.; Jaraminiene, E.; Dudkiewicz, E. 2009. Inherent variability of heat consumption in residential buildings, Energy and Buildings 41(11): 1188-1194. http://dx.doi.org/10.1016/j.enbuild.2009.06.007

Juodis, E. 2013. The application possibilities of energy consumption comparison according the degree-days in lowenergy buildings, Thermal Technics 1: 15-18.

Korolija, I.; Zhang, Y.; Marjanovic-Halburd, L.; Hanby, V. I. 2013. Regression models for predicting UK office building energy consumption from heating and cooling demands, Energy and Buildings 59: 214-227. http://dx.doi.org/10.1016/j.enbuild.2012.12.005

Malmqvist, T.; Glaumann, M.; Scarpellini, S.; Zabalza, I.; Aranda, A.; Liera, E.; Diaz, S. 2011. Life cycle assessment in buildings: the ENSLIC simplified method and guidelines, Energy 36(4): 1900-1907. http://dx.doi.org/10.1016/j.energy.2010.03.026

Medineckienè, M.; Bjork, F. 2011. Owner preferences regarding renovation measures - the demonstration of using multicriteria decision making, Journal of Civil Engineering and Management 17(2): 284-295. http://dx.doi.org/10.3846/13923730.2011.582380

Morelli, M.; Ronby, L.; Mikkelsen, S. E.; Minzari, M. G.; Kidemoes, T.; Tommerup, H. M. 2012. Energy retrofitting of a typical old Danish multi-family building to a "nearly-zero" energy building based on experiences from a test apartment, Energy and Buildings 54: 395-406. http://dx.doi.org/10.1016/j.enbuild.2012.07.046

Risholt, B.; Time, B.; Hestnes, A. G. 2013. Sustainability assessment of nearly zero energy renovation of dwellings based on energy, economy and home quality indicators, Energy and Buildings 60: 217-224.

http://dx.doi.org/10.1016/j.enbuild.2012.12.017

RSN 156-94 Building Climatology. Technical regulation, Lithuania, 1995. [online], [cited 26 June 2013]. Available from Internet: http://www3.lrs.lt/pls/inter3/dokpaieska.showdoc_1?p_id= 237464 (in Lithuanian).

Synnefa, A.; Santamouris, M. 2012. Advances on technical, policy and market aspects of cool roof technology in $\mathrm{Eu}-$ rope: The Cool Roofs Project, Energy and Buildings 55: 35-41. http://dx.doi.org/10.1016/j.enbuild.2011.11.051 
Statistics Lithuania, Sustainable development indicators, Department of Statistics under the Government of the Republic of Lithuania, Vilnius, 2012. [online], [cited 26 June 2013]. Available from Internet: http://www.stat.gov.lt/en/pages/view/?id=3514

STR 1.12.06:2002 Building usage and lifetime. Construction technical regulation. Republic of Lithuania, 2002. [online], [cited 26 June 2013]. Available from Internet: http://www3.lrs.lt/pls/inter3/oldsearch.preps2?Condition1 $=193087 \&$ Condition $2=$ (in Lithuanian $)$.

STR 2.09.04:2008 Capacity of building heating system, Energy input for heating. Construction technical regulation. Republic of Lithuania, 2008. [online], [cited 26 June 2013]. Available from Internet: http://www3.lrs.lt/pls/inter3/dokpaieska.showdoc_1?p_id= $320473 \& p \_q u e r y=\& p \_t r 2=$ (in Lithuanian).

STR 2.05.01:2005 Thermal techniques of building enclosures. Construction technical regulation. Republic of Lithuania, 2005. [online], [cited 26 June 2013]. Available from Internet:

http://www3.lrs.lt/pls/inter3/oldsearch.preps2?Condition1 $=260821 \&$ Condition $2=$ (in Lithuanian $)$.
Štreimikienė, D.; Barakauskaitė-Jakubauskienė, N. 2012. Sustainable development and quality of life in Lithuania compared to other countries, Technological and Economic Development of Economy 18(4): 588-607. http://dx.doi.org/10.3846/20294913.2012.708676

Uihlein, A.; Eder, P. 2010. Policy options towards an energy efficient residential building stock in the EU-27, Energy and Buildings 42(6): 791-798. http://dx.doi.org/10.1016/j.enbuild.2009.11.016

Wang, X.; Kendrick, Ch.; Ogden, R.; Walliman, N.; Baiche, B. 2013. A case study on energy consumption and overheating for a UK industrial building with rooflights, Applied Energy 104: 337-344. http://dx.doi.org/10.1016/j.apenergy.2012.10.047

Vytautas STANKEVIČIUS. Prof. Dr Habil., the author of more than 230 papers and 4 patents. Research interests: physical properties of building materials, physical-technical processes in building envelopes, energy saving in buildings, weather durability of the external finish of building walls.

Jūratė KARBAUSKAITE். Dr, research interests: mass and heat transfer of building constructions, heat losses in buildings energy saving measures.

Arūnas BURLINGIS. Dr, Researcher at the Laboratory of Thermal Building Physics at the Institute of Architecture and Construction, KTU. Research interests: the moisture state of building constructions, physical-technical processes in building envelopes, heat loss in buildings.

Jolanta ŠADAUSKIENÉ. Dr, Researcher at the Laboratory of Thermal Building Physics at the Institute of Architecture and Construction, KTU. Research interests: the moisture state of building constructions, physical-technical processes in building envelopes, heat losses in buildings.

Romaldas MORKVE்NAS. Lecturer at the Department of Building Energy System, Faculty of Civil Engineering and Architecture, Kaunas Technology University. Research interests: sustainable energy of building. 